KONSTAN
JURNAL FISIKA DAN PENDIDIKAN FISIKA
Volume 5, Nomor 1, Juni 2020
E-ISSN : 2460-9129 dan P-ISSN : 2460-9110
http://jurnalkonstan.ac.id/index.php/jurnal

\title{
PENGARUH MODEL PROBLEM BASED LEARNING TERHADAP HASIL BELAJAR FISIKA PESERTA DIDIK MA DARUL HIKMAH DAREK TAHUN PELAJARAN 2019/2020
}

\author{
Baiq Henny Helyandari ${ }^{1)}$, Hairunnisyah Sahidu ${ }^{\text {1) }}$, Hikmawati ${ }^{\text {1** }}$ \\ ${ }^{1)}$ Program Studi Pendidikan Fisika, Fakultas Keguruan dan Ilmu Pengetahuan, \\ Universitas Mataram, Mataram Indonesia
}

\begin{tabular}{l}
\hline Info Artikel \\
\hline Sejarah Artikel: \\
Diterima Maret 2020 \\
Disetujui Juni 2020 \\
Dipublikasikan Juni 2020
\end{tabular}

Kata Kunci:

Model Pembelajaran, Problem based learning, hasil belajar

\begin{abstract}
Abstrak
Penelitian ini bertujuan untuk: mengetahui pengaruh model problem based learning terhadap hasil belajar fisika peserta didik kelas XI MIA di MA Darul Hikmah Darek. Jenis penelitian kuasi eksperimen dengan desain penelitian pretest-postest control group design. Populasi penelitian ini adalah semua peserta didik kelas XI MIA MA Darul Hikmah Darek tahun ajaran 2019/2020. Teknik pengambilan sampel menggunakan sampel jenuh, dengan peserta didik kelas XI MIA 1 sebagai kelas eksperimen dan kelas XI MIA 2 sebagai kelas kontrol. Instrumen yang digunakan untuk mengukur hasil belajar pada ranah kognitif adalah tes objektif yang terlebih dahulu diuji validitas, reliabilitas, daya beda dan taraf kesukaran soal. Nilai rata-rata hasil belajar kelas eksperimen 70,00 dan kelas kontrol 61,25. Hasil uji prasyarat analisis menunjukkan bahwa data posttest terdistribusi normal dan homogen sehingga uji statistik yang digunakan adalah parametrik t-test polled varian dengan kriteria uji t, dan diperoleh thitung 2,08 dan ttabel 2,03 pada taraf signifikan 5\%. Nilai thitung lebih besar dari ttabel maka Ho ditolak dan Ha diterima, sehingga disimpulkan bahwa terdapat pengaruh model Problem based learning terhadap hasil belajar fisika peserta didik MA Darul Hikmah tahun ajaran 2019/2020.
\end{abstract}

(C) 2020 Universitas Islam Negeri Mataram

\footnotetext{
* Corresponding Author: hikmawati@unram.ac.id

Alamat korespodensi:

Program Studi Pendidikan Fisika, Fakultas Keguruan dan Ilmu Pengetahuan, Universitas Mataram, Mataram Indonesia
} 


\section{PENDAHULUAN}

Pendidikan merupakan sarana penting untuk meningkatkan kualitas Sumber Daya Manusia (SDM) dalam menjamin keberlangsungan pembangunan suatu bangsa. Pendidikan memiliki fungsi untuk mengembangkan kemampuan dan karakter manusia. Hal ini sesuai dengan fungsi pendidikan menurut UU No.20 Tahun 2003. Pengembangan kemampuan dan karakter manusia dilakukan dengan menanamkan nilai-nilai karakter diantaranya, berupa pengetahuan dan kesadaran untuk bertindak sesuai nilai-nilai norma baik terhadap Tuhan, diri sendiri, sesama maupun lingkungan. Hal ini dapat dilakukan dengan mengintegrasikan nilai-nilai karakter ke dalam pembelajaran di sekolah.

Pembelajaran sains, khususnya fisika merupakan pembelajaran dimana peserta didik seharusnya dapat dihadapkan langsung dengan objek yang sedang dipelajari, belajar menghubungkan pengetahuan yang dimiliki peserta didik dengan cara yang aktif dan kreatif [1]. Pembelajaran yang paling efektif bagi peserta didik diperoleh melalui model pembelajaran dengan metode belajar sambil mengajar (learning by teaching) artinya bahwa dalam pengajaran oleh guru ada pembelajaran pada peserta didik, pada pembelajaran peserta didik ada pengajaran baik kepada sesama peserta didik atau dalam hal-hal tertentu dari peserta didik terhadap guru [2].

Tujuan pembelajaran fisika sebagai pembelajaran sains adalah untuk meningkatkan pemahaman peserta didik terhadap konsep-konsep fisika dan menerapkannya dalam kehidupan sehari-hari. Tujuan ini dapat tercapai jika model pembelajaran yang digunakan dapat menciptakan interaksi langsung antara peserta didik dengan objek yang dipelajarinya [2].

Berdasarkan hasil observasi awal melalui wawancara dengan guru mata pelajaran fisika di MA Darul Hikmah Darek diperoleh bahwa nilai mata pelajaran fisika peserta didik masih tergolong rendah, hanya beberapa peserta didik yang aktif berpikir dalam menyelesaikan masalah dan tingkat berpikir dalam memahami pelajaran masih rendah. Selain wawancara dengan guru, peniliti juga melakukan wawancara dengan peserta didik sebagian besar menyatakan bahwa mata pelajaran fisika sebagai mata pelajaran yang sulit, karena memiliki sangat banyak rumus yang rumit, peserta didik tidak mengetahui bahwa apa yang mereka pelajari merupakan peristiwa yang setiap hari mereka alami. Peserta didik lebih cenderung menghapal dibandingkan dengan menganalisis masalah. Sehingga apabila peserta didik diberikan masalah yang lebih menekankan analisis mereka akan kesulitan dalam pemecahannya. Akibatnya peserta didik tidak menaruh minat pada pembelajaran fisika sehingga pada hasil belajar yang dicapai masih rendah.

Pemilihan model pembelajaran yang tepat sangat diperlukan untuk mengatasi permasalahan tersebut salah satunya dengan menggunakan model pembelajaran Problem Based Learning (PBL). Menurut Suprijono, model pembelajaran adalah pola yang digunakan sebagai pedoman dalam merencanakan pembelajaran di kelas maupun tutorial [3]. Menurut Ngalimun, PBL merupakan suatu model pembelajaran yang melibatkan peserta didik untuk memecahkan suatu masalah melalui tahap-tahap metode ilmiah sehingga peserta didik dapat mempelajari pengetahuan yang berhubungan dengan masalah tersebut dan sekaligus memiliki keterampilan untuk memecahkan masalah [4]. Dengan 
menggunakan model PBL membutuhkan keterlibatan peserta didik secara aktif dalam kegiatan pembelajaran. Keaktifan peserta didik dalam pembelajaran akan merangsang peningkatan kemampuan pemahaman peserta didik dalam memahami pelajaran. Semakin kuat pemahaman peserta didik terhadap apa yang dipelajarinya maka hasil belajarnyapun akan meningkat.

Menurut Abidin (2014) problem based learning merupakan sebuah model pembelajaran yang menyediakan pengalaman autentik yang mendorong peserta didik untuk belajar aktif, mengkonstruksi pengetahuan, dan mengintegrasikan konteks belajar di sekolah dan belajar di kehidupan nyata secara alamiah [5]. Hal ini sejalan dengan penelitian yang dilakukan oleh Utomo menyatakan bahwa model pembelajaran PBL merupakan pembelajaran yang menuntut aktivitas mental peserta didik untuk memahami suatu konsep pembelajaran melalui situasi dan masalah yang disajikan pada awal pembelajaran dengan tujuan untuk melatih peserta didik menyelesaikan masalah [6]. Hal ini sejalan dengan Trianto. Model PBL didasarkan pada banyaknya permasalahan yang membutuhkan penyelidikan autentik yakni penyelidikan yang membutuhkan penyelesaian nyata dari permasalahan nyata. Model PBL ini lebih menempatkan permasalahan sebagai pusat pembelajaran dan peserta didik secara langsung terlibat dalam pemecahan masalah tersebut.

Dalam pelaksanaannya model problem based learning memiliki beberapa kelebihan diantaranya: (a) Peserta didik akan terbiasa menghadapi masalah dan tantangan untuk menyelesaikan juga masalah yang ada dalam kehidupan seharihari, (b) Dapat masalah tidak hanya terkait dengan pembelajaran di kelas tetapi merangsang pengembangan kemampuan berpikir secara kreatif dan menyeluruh, karena dalam proses pembelajarannya, para peserta didik banyak melakukan proses mental dengan menyoroti permasalahan dari berbagai aspek, (c) Memupuk solidaritas sosial dengan terbiasa berdiskusi dengan teman-teman,(d) Membiasakan peserta didik melakukan eksperimen. Di samping memiliki kelebihan, model problem based learning juga memiliki kelemahan. Adapun yang menjadi kelemahan dalam model pembelajaran ini diantaranya yaitu: (a) Sering terjadi kesulitan dalammenemukan permasalahan yang sesuai dengan tingkat berpikir peserta didik. Hal ini dapat terjadi karena perbedaan tingkat kemampuan berpikir pada peserta didik, (b) Sering memerlukan waktu yang lebih banyak dibandingkan dengan penggunaan metode konvensional belajar dari yang semula belajar mendengar, mencatat dan menghafal (c)Sering mengalami kesulitan dalam perubahan kebiasaan informasi yang disampaikan guru, menjadi belajar dengan cara mencari data, menganalisis, menyusun hipotesis, dan memecahkannya sendiri. Penggunaan model pembelajaran problem based learning oleh para guru dalam kegiatan pembelajaran yang diharapkan dapat memberikan pengaruh dampak positif terhadap meningkatnya hasil belajar peserta didik yang khususnya pada mata pelajaran fisika.

\section{METODE PENELITIAN}

Penelitian ini merupakan penelitian quasi experiment (eksperimen semu), dengan desain penelitian yaitu pretest-posttest control group design. Pada rancangan penelitian ini sampel dibagi dalam dua kelas yaitu kelas eksperimen dan 
kelas kontrol. Pembelajaran menggunakan model problem based learning pada kelas eksperimen dan model pembelajaran konvensional pada kelas kontrol. Instrumen tes hasil belajar menggunakan tes objektif (pilihan ganda) dengan jumlah 20 soal pada materi elastisitas dan hukum Hooke dengan subjek penelitian adalah peserta didik kelas XI MIA di MA Darul Hikmah Darek. Kelas XI MIA 2 sebagai kelas eksperimen dan kelas XI MIA 1 sebagai kelas kontrol dengan teknik sampling jenuh. Data hasil belajar diuji prasyarat, berupa uji homogenitas dan uji normalitas. Kemudian dilanjutkan dengan uji hipotesis menggunakan uji t Polled Varians.

\section{HASIL DAN PEMBAHASAN}

Penelitian ini bertujuan untuk mengetahui pengaruh model problem based learning terhadap hasil belajar fisika peserta didik. Perlakuan yang diberikan pada kelas ekperimen (XI MIA 2) berupa pembelajaran model PBL sedangkan pada kelas kontrol (XI MIA 1) perlakuan yang diterapkan konvensional. Kedua kelas sebelum diberikan perlakuan diberikan tes awal (pre-test). Dengan tujuan untuk mengetahui pengetahuan awal peserta didik dalam kelas tersebut. Hasil belajar untuk kelas eksperimen dan kontrol sebelum diberikan perlakuan sangat rendah yaitu nilai terendah pada kelas eksperimen adalah 20, sedangkan nilai terendah pada kelas kontrol adalah 10. Nilai tertinggi pada kelas eksperimen adalah 55, sedangkan nilai tertinggi pada kelas kontrol adalah 40. Rata-rata nilai tes awal kelas eksperimen adalah 40,28 dan kelas kontrol adalah 26,47.

Data tes awal hasil belajar fisika peserta didik pada kelas eksperimen dan kontrol disajikan pada Gambar 1.

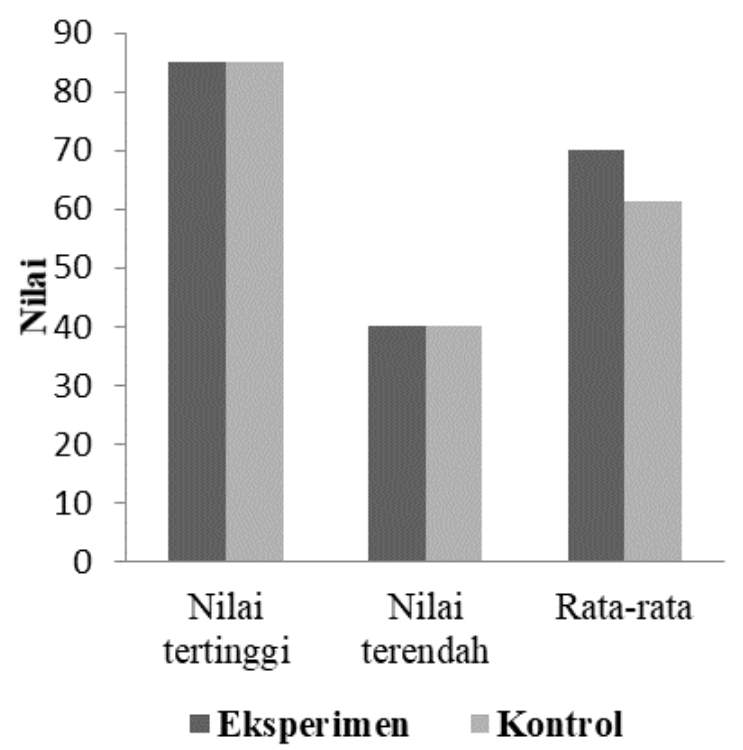

Gambar 1. Data Tes Awal Hasil Belajar

Setelah kedua kelas diberikan tes awal (pretest), maka kelas eksperimen dan kontrol diberikan perlakuan yang berbeda yaitu kelas eksperimen diajar dengan 
menerapkan model PBL dan kelas kontrol diajar dengan pembelajaran konvensional. Setelah diberikan perlakuan kelas eksperimen dan kontrol diberikan tes akhir (posttest) untuk melihat apakah ada pengaruh perlakuan yang sudah diberikan pada kelas eksperimen yang dibandingkan dengan kelas kontrol.

Nilai rata-rata yang diperoleh untuk kelas eksperimen lebih tinggi dibandingkan dengan kelas kontrol yaitu 70,00 untuk kelas eksperimen dan 61,18 untuk kelas kontrol. Nilai tertinggi dan nilai terendah untuk kelas eksperimen sama dengan kelas kontrol yaitu 85 untuk nilai tertinggi dan 40 untuk nilai terendah pada kelas eksperimen dan 85 untuk nilai tertinggi dan 40 untuk nilai terendah pada kelas kontrol. Data tes akhir hasil belajar fisika peserta didik pada kelas eksperimen dan kontrol disajikan pada Gambar 2.

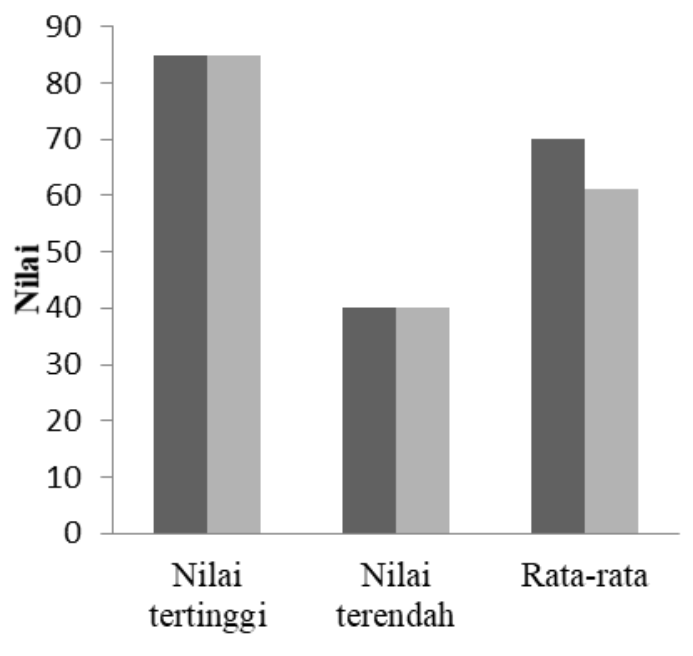

\section{- Eksperimen $\quad$ Kontrol}

Gambar 2. Data Tes Akhir Hasil Belajar

Hasil tes akhir kedua kelas mengalamii peningkatan dibandingkan dengan hasil tes awal.. Dari data hasil tes akhir (posttest) nilai rata-rata yang didapatkan oleh peserta didik kelas eksperimen adalah 70,00 dengan jumlah peserta didik sebanyak 18 orang dan nilai rata-rata pada kelas kontrol adalah 61,18 dengan jumlah peserta didik sebanyak 17 orang. Hal ini berarti perlakuan yang diberikan kepada kelas eksperimen memberikan pengaruh terhadap hasil belajar peserta didik. Ada beberapa faktor yang menyebabkan adanya pengaruh pemberian perlakuan terhadap hasil belajar peserta didik, salah satunya adalah pemberian perlakuan berupa model problem based learning dengan menggunakan metode eksperimen pada kelas eksperimen, sedangkan pada kelas kontrol menggunakan pembelajaran konvensional dengan metode diskusi. Alat dan bahan yang digunakan disesuaikan dengan kondisi nyata peserta didik, sehingga dapat mempermudah mempelajari dan memahami materi yang diajarkan. 
Menurut Azmi, hasil belajar dapat dijelaskan dengan memahami dua kata yang membentuknya, yaitu "hasil" dan "belajar". Pengertian hasil mengarah pada suatu perolehan akibat dilakukannya suatu aktivitas atau proses yang mengakibatkan berubahnya input secara fungsional [7]. Menurut Purwanto, perubahan pada diri individu dari segi kognitif, afektif, maupun psikomotor yang didapatkannya sebagai akibat dari suatu proses belajar [8]. Hasil belajar perlu dievaluasi. Evaluasi dimaksudkan sebagai cermin untuk melihat kembali apakah tujuan yang ditetapkan telah tercapai dan apakah proses pembelajaran telah berlangsung efektif untuk memperoleh hasil belajar. Sudjana mengatakan bahwa hasil belajar tidak dapat diperoleh secara langsung tetapi harus melalui proses pembelajaran terlebih dahulu [9]. Hasil tersebut berupa kemampuan-kemampuan yang dimiliki setelah menerima pengalaman belajarnya. hasil belajar seringkali digunakan sebagai ukuran mengetahui seberapa jauh seseorang menguasi bahan yang sudah diajarkan. Aziz, dkk berpendapat bahwa hasil belajar adalah akibat dari suatu proses yang dilakukan oleh siswa dan guru di dalam kelas, siswa berusaha memperoleh pelajaran (belajar) dan guru memberikan pelajaran (mengajar) [10]. Faktor yang mempengaruhi hasil belajar siswa dikelompokkan menjadi dua yaitu faktor internal dan faktor eksternal. Faktor internal meliputi fisik dan psikis seperti minat, kesehatan dan motivasi, sedangkan faktor eksternal meliputi guru, sarana dan prasarana, kurikulum dan lain-lain.

Selama proses pembelajaran, peserta didik kelas eksperimen cendrung lebih menikmati pembelajaran yang dipadukan dengan kegiatan eksperimen yang baru mereka lakukan. Di kelas kontrol yang menggunakan pembelajaran konvensional, guru hanya menjelaskan dan peserta didik kemudian mencatat apa yang dijelaskan oleh guru. Cara ini ternyata menyebabkan peserta didik kesulitan untuk memahami konsep yang dipelajari. Kesulitan ini disebabkan kurangnya kemampuan peserta didik untuk memahami konsep-konsep fisika. Penilaian aspek afektif juga dapat mempengaruhi hasil belajar yang diperoleh setiap peserta didik. Penilaian afektif didapatkan dengan memberikan skor setiap sikap yang ditampilkan oleh peserta didik selama proses pembelajaran. Dengan melihat penilain afektif untuk kelas eksperimen dengan skor minimal 11 dengan nilai 3,00 dan skor maksimal 16 dengan nilai 4,00. Untuk kelas kontrol dengan jumlah peserta didik 17 orang didapatkan skor minimal 8 dengan nilai 2,00 dan skor maksimal 16 dengan nilai 4,00. Selain penilaian afektif ada juga penilaian psikomotor. Data penilaian aspek psikomotor diperoleh dengan cara peneliti memberikan skor sesuai dengan aktifitas yang dilakuakan oleh peserta didik selama proses pembelajaran. Untuk penilaian psikomotor yang diperoleh kelas eksperimen dalam aspek psikomotor didapatkan skor minimal sebesar 13 dengan nilai 81,25 dan skor maksimal sebesar 16 dengan nilai 100. Kelas kontrol didapatakan skor minimal 12 dengan nilai 75,00 dan untuk skor maksimal didapatkan skor sebesar 16 dengan nilai 100.

Data hasil posttest menunjukkan terdapat perbedaan rata-rata hasil belajar peserta didik kelas eksperimen dan kelas kontrol. Terlihat hasil posttest eksperimen lebih tinggi daripada kelas kontrol. Hasil uji hipotesis, didapatkan $t_{\text {hitung }}>t_{\text {tabel }}$ yaitu 2,08>2,03 pada taraf signifikan 5\%, sehingga disimpulkan model PBL berpengaruh terhadap hasil belajar Fisika peserta didik MA Darul Hikmah Darek Tahun Pelajaran 2019/2020. 
Model problem based learning yang diterapkan pada kelas eksperimen memiliki keunggulan berupa peserta didik dapat membiasakan diri menghadapi dan memecahkan masalah secara terampil, dapat merangsang dan mengembangan kemampuan berpikir secara kreatif dan menyeluruh dalam proses pembelajaran peserta didik dilatih untuk menyoroti permasalahan dari berbagai aspek. Kegiatan pembelajaran pada kelas eksperimen dirancang berdasarkan karakteristik model pembelajaran PBL yang tercermin didalam langkah pembelajaran tersebut. masalah sebagai fokus utama pembelajaran disajikan dalam LKPD yang berbasis PBL [6].

Masalah yang disajikan dalam pembelajaran merupakan permasalahan yang ada dalam kehidupan sehari-hari. Hal tersebut dapat membuat peserta didik termotivasi dan merasa antusias untuk belajar serta menggali pengetahuan secara mandiri dan kelompok untuk menyelesaikan permasalahan. Masalah yang disajikan tidak hanya sekedar disajikan begitu saja, tetapi peserta didik dituntut untuk mencari solusi dari penyelesaian masalah tersebut. Solusi dari penyelesaiana masalah dicari bersama-sama anggota kelompok lain.

Pembelajaran konvensional dengan metode ceramah dan tanya jawab. Dengan metode konvensional tersebut, peserta didik cendrung merasa bosan, peserta didik sibuk sendiri dan tidak fokus ketika berlangsungnya proses pembelajaran. Hasil yang kurang baik pada kelas kontrol dibandingkan kelas eksperimen disebabkan pada kelas kontrol peserta didik hanya mendengarkan dan mencatat setiap informasi yang disampaikan oleh guru. Hal ini membuat peserta didik kurang berperan secara aktif dan antusias dan hasil belajar peserta didik rendah, sehingga dapat mempengaruhi hasil belajar peserta didik menjadi rendah pula. Pada perhitungan $N$-gain pada kedua kelas yang bertujuan untuk membandingkan peningkatan hasil tes awal dengan tes akhir, diantara kelas eksperimen dan kelas kontrol pada setiap sub materi. Dari hasil yang didapatkan menunjukkan peningkatan pada kelas eksperimen lebih tinggi daripada kelas kontrol.

\section{SIMPULAN DAN SARAN}

Data hasil posttest menunjukkan terdapat perbedaan rata-rata hasil belajar peserta didik kelas eksperimen dan kelas kontrol. Terlihat hasil posttest eksperimen lebih tinggi daripada kelas kontrol. Hasil uji hipotesis, didapatkan $t_{\text {hitung }}>t_{\text {tabel }}$ yaitu 2,08>2,03 pada taraf signifikan 5\%, sehingga disimpulkan model PBL berpengaruh terhadap hasil belajar Fisika peserta didik MA Darul Hikmah Darek Tahun Pelajaran 2019/2020.

\section{DAFTAR PUSTAKA}

[1] Ibrahim, M. 2008. Asesmen Berkelanjutan. Surabaya: Unesa Universitas Press.

[2] Suyono dan Harianto. 2011. Belajar dan Pembelajaran. Surabaya: Remaja Rosdakarya. 
[3] Suprijono, A. 2012. Cooperative Learning Teori dan Aplikasi Paikem. Yogyakarta: Pustaka Belajar.

[4] Ngalimun, 2014. Strategi dan Model Pembelajaran. Yogyakarta: Aswaja Pressindo

[5] Abidin, Yunus. 2014. Desain Pembelajaran Dalam Konteks Kurikulum 2013. Bandung. PT Refika Aditama.

[6] Utomo, Tomi, Wahyuni, Dwi, Hariyadi, Slamet. 2014. Pengaruh Model Pembelajaran Berbasis Masalah (Problem Based Learning) Terhadap Pemahaman Dan Kemampuan Berpikir Kreatif Siswa. Jurnal Edukasi UNEJ. Vol. $1: 5-9$.

[7] Azmi, Khairul, Muhamad, Rahayu, Satutik, Hikmawati. 2016. Pengaruh model problem based learning dengan metode eksperimen dan diskusi terhadap hasil belajar fisika ditinjau dari sikap ilmiah siswa kelas X MIPA SMA N 1 Mataram. Jurnal Pendidikan Fisika Dan Teknologi. Vol. II, No.2.

[8] Purwanto. 2013. Evaluasi Hasil Belajar. Surakarta: Pustaka Pelajar.

[9] Sudjana, N. 2013. Dasar-Dasar Proses Belajar Mengajar. Bandung: Sinar Baru Algensido.

[10] Aziz, Abdul, Yulianti, Dwi, Handayani, Langlang. 2006. Penerapaan Model Pembelajaran Dengan Memanfaatkan Alat Peraga Sainsfisika Untuk Meningkatkan Hasil Belajar Dan Kerja Sama Siswa. Jurnal Pendidikan Fisika Indonesia. Vol.4, No.2. 